\title{
DOES TRADE LIBERALISATION MATTER ?: An Analysis of Intra-Industry Trade for Turkey and the EU
}

\author{
Levent Kösekahyaoğlu*
}

\begin{abstract}
In assessing the implications of trade liberalisation, examination of whether any expansion in trade was primarily inter-industry or intra-industry in nature is crucial as it can provide some insight into the potential consequences of further trade liberalisation (e.g. Turkey's accession to the EU). As a consequence of Turkey's trade liberalisation attempts with the EU, one can expect that as trade barriers between Turkey and the EU are removed Turkey can further exploit its comparative advantage and therefore that inter-industry trade will develop between the two areas. Among countries with similar factor endowments, one can also expect that scale economies will be further exhausted and hence that intra-industry trade will increase. Therefore, it is of interest to examine the trend of intra-industry trade between Turkey and the EU over pre-and post liberalisation periods as this can shed some light on nature of trade expansion between the two areas which be very useful for studying effects of further economic integration of Turkey into the $E U$.
\end{abstract}

\section{Introduction}

This paper examines the trend of intra-industry trade (IIT) for Turkey over the pre- and post-liberalisation periods and particularly focuses on the extent of IIT in Turkey-EU trade. The main aim of the paper is to investigate the relation between trade liberalisation, structural adjustment and IIT for the case of Turkey-EU trade. The link between trade liberalisation and IIT is tested by employing Grubel-Lloyd indices.

Dr., Research Assistant at Suleyman Demirel University, Faculty of Economic and Administrative Sciences. 
A number of questions with important implications for economic policy revolve around the impact of trade liberalisation on levels of intra-industry trade (IIT) and costs of structural adjustment. Firstly, does trade liberalisation through, say, the formation of a free trade area, stimulate a greater degree of IIT? Secondly, are the adjustment costs to trade liberalisation lower in industries characterised by high degrees of IIT? (see Globerman and Dean (1990), Globerman (1992), Menon and Dixon (1997) for further discussions).

In order to answer the first question, Caves (1981) tests whether natural and artificial barriers (i.e. non-trade barriers -NTB's ) to trade discourage trade of the IIT type. Caves is not convinced that there are good theoretical reasons for the relationship and his doubts are confirmed by his results. On the other hand, Balassa and Bauwens (1987) test for a negative relation between the height of trade barriers and IIT and a positive correlation between IIT and participation in economic unions. Their results provide strong support for both of these propositions. The implication of their result is that trade liberalisation due to customs unions stimulates trade of the intra-industry type.

Regarding the second question, the nature of trade has important implications for the process of structural adjustment to trade liberalisation and the extent of costs to be borne. It is generally argued that adjustment costs are lower when new trade is intra-industry type because disruption is minimised when adjustment is internal to an industry ${ }^{1}$. The reason for this is that it is easier to transfer and adapt resources within firms or industries than to switch them from one industry to another. Krugman (1981) has formally shown that when countries have sufficiently similar factor endowments, both partners tend to gain from trade liberalisation and the consequent IIT poses fewer adjustment problems than in the standard case.

Given the ambiguity of theoretical arguments on the possible link between trade liberalisation and IIT, this work aims at further examining a causal relationship between liberalisation and IIT for Turkey. This is, however, not an easy task. As Caves (1981) argues, if two countries have some intra-industry trade and then liberalise their bilateral trade, an equiproportionate increase in exports of each country will raise the amount of IIT but will not raise the proportion of it. To overcome this obstacle, I 
use not only the traditional Grubel-Lloyd indices of IIT but also a new measure - the index of marginal intra-industry trade (MIIT)- which measures the degree of IIT in new trade.

The rest of the paper is arranged as follows. The next section, firstly, investigates the theoretical and empirical arguments on the potential correlation between freeing trade and IIT. This section also briefly summarises short comings of traditional Heckscher-Ohlin $(\mathrm{H}-\mathrm{O})$ type theories in explaining trade flows and introduces the recent new trade theory (NTT) and new economic geography (NEG) models. Section 3 defines the measures of IIT employed and tests whether Turkey's 1980 trade liberalisation stimulated IIT. Section 3 also examines IIT in new trade created after the trade liberalisation by using marginal IIT (MIIT) indices. The last section draws some conclusions on the results.

\section{Trade Liberalisation, Structural Adjustment and IIT}

\subsection{The relation between trade liberalisation and IIT}

Research on IIT has generated a lot of stimulating approaches to the development of international trade theory in the last three decades. The reason for this intensive work is the difficulty of finding comfortable explanations of the phenomenon of IT within the framework of the traditional H-O theory of trade. Recent research has advocated the need for complementing the factor endowment approach to international trade with other theories, notably those emphasising the role of scale economies and product differentiation ${ }^{2}$. The emergence of these new theories of IIT, namely the new trade theory (NTT) and the new economic geography (NEG), can essentially be attributed to the empirical finding of high and growing shares of IIT which has been deemed incompatible with neoclassical H-O models ${ }^{3}$.

As mentioned in the introduction, there is no clear-cut theoretical basis on the relationship between trade liberalisation and IIT. In the traditional $\mathrm{H}$ $O$ model, trade flows are primarily driven by national differences in comparative advantage. The implication of this model is that trade liberalisation could lead to potentially substantial inter-industry reallocation of resources within countries as economic activity is geographically 
rationalised to conform more closely to patterns dictated by differences in relative factor prices. The models of new trade theory (NTT), however, introduce activity-specific features such as imperfect competition, differentiated products and increasing returns. The typical outcome of NTT models has two layers. First, there is inter-industry specialisation, with sectors clustering in locations which offer best access to product markets. Second, there is intra-industry specialisation across firms, each of which produces a unique, horizontally differentiated variety of the industry's product. Thus, as long as some firms are left in the smaller market, IIT will ensue. However, as trade costs fall towards zero, all increasing returns activity will tend to concentrate near the core market and IIT between the core and the periphery disappears.

Similar to the theoretical arguments, the empirical work which investigates if trade liberalisation stimulates more IIT is inconclusive too ${ }^{4}$. Though Balassa and Bauwens (1987) find strong empirical support for a positive correlation between trade liberalisation and IIT, the most celebrated model of the NTT, Krugman (1980), predicts that, as trade barriers are reduced, increasing-returns industry concentrates in the large market. Therefore, the share of IIT should tend to zero with trade liberalisation. More recently, the results of Hamilton and Kniest (1991) provide no support for the proposition that trade liberalisation encourages IIT $^{5}$. Given this picture of empirical studies on the association between trade liberalisation and IIT, great care needs to be taken in interpreting empirical findings as corroboration or rejection of theoretical models.

\subsection{The relation between structural adjustment and IIT}

The impact of trade liberalisation on the extent of structural adjustment is another area of interest as assessment of the welfare effects of trade liberalisation depends on the relation between adjustment costs and IIT. Though structural adjustment is a difficult concept to define and measure, a number of studies have constructed some indicators which reflect changes in certain important characteristics of industry structure ${ }^{6}$. Some of them are: changes in the number of establishments, changes in employment, changes in turnover and changes in labour productivity (turnover per worker) in each industry. Intuitively it can be argued that under the impact of trade liberalisation, structural change is felt more strongly in industries 
with low levels of IIT. We would expect this to be the case as industries with high levels of IIT would be more likely to experience adjustment within the industry, reflected in a smaller net change in the number of establishments, employment and turnover ${ }^{7}$.

The connection between trade liberalisation and structural adjustment is a crucial issue in assessing impact of economic integration. The possibility of lower adjustment cost suggests that the prospects for a common market are higher when more of existing and potential trade is of the intra-industry type. Marvel and Ray (1987) argue on political economy grounds that high levels of IIT make trade protection more difficult to secure and the freeing of trade meets less resistance.

Although it is hard to establish a conclusive a priori case for the contention that adjustment will always be smoother in a setting of intraindustry trade compared with a setting of inter-industry trade, it nevertheless appears reasonable to suppose that adjustment frictions of some form may still exist. Cox and Harris (1985), for example, provides a general equilibrium assessment of the impact of unilateral and multilateral trade liberalisation in Canada. Their work also offers some comments on the adjustment issue. This work finds that in both the unilateral and multilateral trade liberalisation scenarios imports and exports expand in all sectors. Moreover, in both cases intra-sectoral resource reallocation dominated intersectoral reallocation. For instance, in the multilateral liberalisation case only 6 per cent of the labour force is reallocated intersectorally. This suggests to the authors that 'the adjustment costs of adopting a free trade policy may not be large' (pp.140). Therefore, the simulations seem to provide strong support for the view that adjustment to trade expansion may be smother in an economy where a significant degree of intra-industry specialisation is possible. [see also Adler (1970) and Andreosso and Noonan (1996)]

\section{Theoretical and Empirical Background on IIT}

\subsection{Overview}

In this section, first, I give a brief overview on trends in IIT and summarise theoretical and empirical arguments on the measurement of IIT 
and problems with the measurement procedure. Secondly, using trade data, I examine the pattern of IIT for Turkey over the period between 1975 and 1990 and test if there has been a change in the IIT pattern after implementation of Turkey's liberalisation program in the1980s. Thirdly, considering the shortcomings of traditional IIT indices, I examine IIT in new trade created after the trade liberalisation using marginal IIT (MIIT) indices.

\subsection{Measurement of IIT}

Several theoretical measures of IIT -the two-way trade of goods falling under the same industry classification- have been proposed in the literature. Analyses have been conducted using either a cross section of industries, ${ }^{8}$ a cross section of countries [e.g., Globerman and Dean (1990), Balance et al. (1992)], or a multi-country multi-commodity framework [e.g. Loertscher and Wolter (1980), Balassa (1986), Balassa and Bauwens (1987), and Ballance et al.(1992))

The most widely used measure is the Grubel-Lloyd (GL) (1975) index. In this index, IIT in industry $i$ for country $j$ is:

$$
\operatorname{IIT}_{\mathrm{ij}}=\left[\left(\mathrm{X}_{\mathrm{ij}}+\mathrm{M}_{\mathrm{ij}}\right)-\left|\mathrm{X}_{\mathrm{ij}}-\mathrm{M}_{\mathrm{ij}}\right|\right] /\left(\mathrm{X}_{\mathrm{ij}}+\mathrm{M}_{\mathrm{ij}}\right),
$$

In its contracted form:

$$
\operatorname{IIT}_{\mathrm{ij}}=1-\left|\mathrm{X}_{\mathrm{ij}}-\mathbf{M}_{\mathrm{ij}}\right| /\left(\mathrm{X}_{\mathrm{ij}}+\mathbf{M}_{\mathrm{ij}}\right),
$$

where $\mathrm{X}_{\mathrm{i}}$ is exports of industry $i, \mathrm{M}_{\mathrm{i}}$ is imports of industry $i,\left|\mathrm{X}_{\mathrm{ij}}-\mathrm{M}_{\mathrm{ij}}\right|$ is net trade,

$\left(\mathrm{X}_{\mathrm{ij}}+\mathrm{M}_{\mathrm{ij}}\right)$ is total trade, $\mathrm{i}=1,2,3 \ldots \mathrm{n}$, and $0 \leq \mathrm{IT}_{\mathrm{j}} \leq 1$. In equation (2), an index value of 'zero' would indicate complete inter-industry trade. In this case, either the value of exports or imports would be zero. Higher index values are associated with greater intra-industry trade as a proportion of total trade, with an index value of 'one' indicating equality between exports and imports. 
In the literature on IIT, there are some arguments on validity of the IIT index in equation (2). Firstly, it is argued that when equation (2) is aggregated across industries to form a weighted average IIT measure, the resulting index will not attain the desired maximum value of 1 if the country's total commodity trade is imbalanced. As a result of this finding, GL (1975) argue that such measures of IIT must be adjusted for the aggregate trade imbalance. Many succeeding studies calculate IIT measures that have been corrected for the overall imbalance between imports and exports.

However, according to Vona (1991), and Kol and Mennes (1989), measures of IIT should not be corrected for the overall trade imbalance. Vona employs arithmetic examples to establish the superiority of GL's uncorrected index over corrected indices which appear in the literature. Based on these, and other arguments advanced by the same authors, this work employs the standard uncorrected GL measure of IIT'.

Secondly, several studies have argued that observed values of IIT tend to be lower at higher levels of sectoral disaggregation, and IIT values are therefore difficult to interpret [see Lipsey (1976), for example]. In the literature, this has been referred as the "categorical aggregation problem"10. Studies by GL (1975) and Brulhart and McAleese (1995) indicate that IIT dynamics are remarkably robust to differences in the level of sectoral aggregation. As Brulhart (1998) argues, the industry definition problem therefore seems to be a weak argument against reading real significance into the secular rise of observed IIT. Considering the "categorical aggregation problem", this work will test if sectoral disaggregation matters by estimating and comparing the standard GL indices at two digit SITC (for 63 industries) and at three digit SITC (for 231 industries) for Turkey over the same time period.

Early empirical investigation of IIT had been confined to "static" indicators such as the standard GL index, which measure IIT for one year. However, a paper by Hamilton and Kniest (1991) has revealed a new and potentially challenging dimension to the empirical analysis of IIT by suggesting a measure of marginal intra-industry trade (MIIT). In recent literature on IIT, it is argued that, in order to infer conclusions on adjustment from measurement of IIT, it is conceptually necessary to analyse 
the pattern of change in trade flows rather than comparing the composition of trade at different time points in time. Three methods have been proposed to date for the 'dynamic' analysis of IIT; namely, the Hamilton-Kniest index, the Greenaway et al. index ${ }^{11}$ and the Grubel-Lloyd style measure of MIIT $^{12}$. In this work I employ the Grubel-Lloyd style MIIT indices because they share all statistical properties of the standard GL index. The MIIT index I used is given as;

$\operatorname{MIIT}_{i}=1-\left[\left|\left(X_{t}-X_{t-n}\right)-\left(M_{t}-M_{t-n}\right)\right|\right] /\left[\left|\left(X_{t}-X_{t-n}\right)+\left(M_{t}-M_{t-n}\right)\right|\right]$ (3)

where $X_{t}\left(M_{t}\right)$ and $X_{t-n}\left(M_{t-n}\right)$ are exports and (imports) of a particular industry $i$ in years $t$ and $t-n, n$ standing for the number of years separating the two years of measurement. The MIIT index in equation 3 can also be written as:

$\operatorname{MIIT}_{\mathrm{i}}=1-[|\Delta \mathrm{X}-\Delta \mathrm{M}|] /[|\Delta \mathrm{X}|+|\Delta \mathrm{M}|]$

where $\Delta$ shows change. This index, like the standard GL measure, varies between 0 and 1 , where 0 indicates marginal trade in the particular industry to be completely of the inter-industry type, and 1 represents marginal trade to be entirely of the intra-industry type ${ }^{13}$.

Two important conclusions can be drawn from the empirical literature on IIT, one positive and one negative. The positive conclusion is that studies of IIT provide support for theoretical approaches which go beyond the neoclassical H-O framework. This suggests that a large and increasing part of the forces which drive international trade are different from those identified in H-O theory. The negative conclusion is that the available evidence on IIT patterns does not lend strong support to the approach taken in most of the new trade theories. The general trend is for the trade share of IIT to grow parallel with the lowering of trade costs (e.g. trade liberalisation). As mentioned before, however, this conflicts with the prediction of the standard new trade theory [e.g. Krugman (1980)]. 


\subsection{Estimates of IIT indices for Turkey}

\subsubsection{Analysis of the amount and the proportion of IIT}

The aim of this section is to examine the amount and the proportion of IIT for Turkey and test if there has been any change after the trade liberalisation. This section starts with an analysis of the amount of IIT for Turkey and investigates if categorisation of industries accounts for measuring the amount of IIT. Secondly, I study the proportion of IIT for Turkey over the post-liberalisation period (1980-1990) using MIIT indices. Thirdly, I compare the level of IIT for Turkey's total trade with that of its trade with the EU12. Finally, I give a country and industry specific analysis of IIT for Turkey.

To examine the amount of IIT, I estimate average unadjusted GL indices of IIT in equation (2) for Turkey at both the two-digit SITC (for 63 industries) and at the three-digit SITC (for 231 industries) over the period between 1975 and $1990^{14}$. The results are presented in Table 1 .

Table 1, first, shows that, as one might expect, categorisation of industries matters in measuring IIT since the IIT indices at the two-digit appear to be significantly different (greater) than those at three-digit in all cases (with exception of manufacture in 1975). Secondly, and more importantly, it appears that the level of IIT, especially in manufactured goods, has notably increased following the 1980 trade liberalisation program of Turkey though there has been a slight fall in the case of nonmanufactured goods ${ }^{15}$. This increased pattern of IIT for Turkey after trade liberalisation is confirmed by estimations at both the two-digit and the three-digit level. 
Table 1: Intra-industry trade indices for Turkey ${ }^{1}$

\begin{tabular}{|l|c|c|c|c|}
\hline Commodity Groups (SITC) & 1975 & 1980 & 1985 & 1990 \\
\hline \multicolumn{5}{|c|}{ 63 SITC 2-Digit Groups ${ }^{2}$} \\
\hline Non-Manufactured (0-4) & 0.33 & 0.21 & 0.34 & 0.39 \\
\hline Manufactured (5-8) & 0.21 & 0.26 & 0.38 & 0.41 \\
\hline Overall (0-8) & 0.25 & 0.24 & 0.37 & 0.41 \\
\hline \multicolumn{5}{|c|}{ 231 SITC 3-Digit Groups ${ }^{2}$} \\
\hline Non-Manufactured (0-4) & 0.28 & 0.20 & 0.24 & 0.26 \\
\hline Manufactured (5-8) & 0.22 & 0.23 & 0.31 & 0.32 \\
\hline Overall (0-8) & 0.23 & 0.23 & 0.29 & 0.30 \\
\hline
\end{tabular}

Notes: 1.- The Grubel-Lloyd (unadjusted) index was calculated for each industry and unweighted averages were calculated across industries. 2.- Groups with unidirectional trade have not been included (i.e. where either exports or imports are zero).

As mentioned earlier, the standard GL indices of IIT have some shortcomings as they only indicate the amount of IIT but not changes in the proportion of it in new trade. Therefore, in order to examine the changes in proportion of IIT for Turkey after trade liberalisation, I employ the index of marginal intra-industry trade (MIIT)- which measures the degree of IIT in new trade- over the period between 1980 and 1990. Table 2 below shows the MIIT indices (calculated according to equation 4) for Turkey's total trade and for its trade with the EU12 over the pre-liberalisation (1975-1980) and postliberalisation (1980-1990) periods.

Table 2 illustrates that about 32 (22) percent of Turkey's total trade in manufactured (non-manufactured) goods was in the form of intraindustry trade over the pre-liberalisation period between 1975 and 1980. However, about 45 (43) percent of new trade created between 1980 and 1990 in manufactured (non-manufactured) goods was intraindustry type. Similarly, about 24 (29) percent of Turkey's trade with the EU12 in manufactured goods (non-manufactured goods) was in the form of intra-industry trade over 1975 and 1980 . The proportion of IIT between Turkey and the EU12 in manufactured and non- 
manufactured goods has reached 34 and 33 percent respectively over the post liberalisation period (1980-1990).

Table 2 : Marginal Intra Industry Trade (MIT) indices for Turkey's total trade and for Turkey's trade with the EU12 for the periods $1975-1980$ and $1980-1990$

\begin{tabular}{|c|c|c|}
\hline \multicolumn{3}{|c|}{ Marginal Intra Industry Trade (MIIT) for Turkey's total trade } \\
\hline Commodity Groups (SITC) & $1975-1980$ & 1980-1990 \\
\hline Non-Manufactured $(0-4)$ & 0.22 & 0.43 \\
\hline Manufactured (5-8) & 0.32 & 0.45 \\
\hline Overall $(0-8)$ & 0.29 & 0.44 \\
\hline \multicolumn{3}{|c|}{ Marginal Intra Industry Trade (MIIT) for Turkey's trade with the EU12 } \\
\hline Non-Manufactured (0-4) & 0.29 & 0.33 \\
\hline Manufactured (5-8) & 0.24 & 0.34 \\
\hline Overall (0-8) & 0.25 & 0.34 \\
\hline
\end{tabular}

Notes: 1.- Marginal Grubel-Lloyd (unadjusted) index, MIIT, was calculated for each industry and unweighted averages were calculated across industries.

Our analysis so far suggests that Turkey's trade liberalisation program endorsed intra-industry type of trade especially in manufactured goods. It appears that freeing trade flows influenced not only the amount but also the proportion of IIT in new trade created over the liberalisation period. Tables 1 and 2 give considerable support to the proposition that trade liberalisation encourages intraindustry type of trade.

\subsubsection{Comparison of IIT for Turkey's total trade with its trade with the EU12}

In what follows I examine if IIT indices for Turkey's total trade differ from its trade with the EU12. Table 3 gives a comparison of IIT indices for Turkey overall trade with Turkey's biggest trading partner, the EU, at SITC two-digit level.

It is clear from Table 3 that the level IIT for Turkey's trade with the EU12 in manufactured goods has increased from 12 percent to 33 percent between 1975-1990 while IIT in non-manufactured goods has 
slightly decreased from 37 percent to 35 percent over the same period. One possible reason for this can be due to the fact that Common Agricultural Policy (CAP) of the EU notably restricts trade flows between non-member countries and the $\mathrm{EU}$ in non-manufactured (agricultural) goods.

Table 3: Comparison of Intra Industry Trade (IIT) Indices for Turkey's Total Trade with Turkey's Trade with the EU12 at SITC 2-digit

\begin{tabular}{|l|c|c|c|c|}
\hline Commodity Groups (SITC) & 1975 & 1980 & 1985 & 1990 \\
\hline \multicolumn{5}{|c|}{ IIT Indices for Turkey's total trade } \\
\hline Non-Manufactured (0-4) & 0.33 & 0.21 & 0.34 & 0.39 \\
\hline Manufactured (5-8) & 0.21 & 0.26 & 0.38 & 0.41 \\
\hline Overall (0-8) & 0.25 & 0.24 & 0.37 & 0.41 \\
\hline \multicolumn{5}{|c|}{ IIT Indices for Turkey's trade with the EU12 } \\
\hline Non-Manufactured (0-4) & 0.37 & 0.23 & 0.31 & 0.35 \\
\hline Manufactured (5-8) & 0.12 & 0.17 & 0.31 & 0.33 \\
\hline Overall (0-8) & 0.21 & 0.19 & 0.31 & 0.34 \\
\hline
\end{tabular}

Notes: 1.- The Grubel-Lloyd (unadjusted) index was calculated for each industry and unweighted averages were calculated across industries. 2.- Groups with unidirectional trade have not been included (i.e. where either exports or imports are zero).

Table 3 also suggests that the level of IIT for Turkey's total trade has been mostly greater than that of Turkey's trade with the EU except for non-manufactured goods in 1975 and 1980.

\subsubsection{A country specific analysis of IIT for Turkey}

Table 4 presents a country specific analysis of IIT in manufactures (SITC 5-8) for Turkey's trade with six selected EU countries three of which are highly industrialised (namely, Germany, the UK and France) and three of which are less industrialised (namely, Spain, Greece and Portugal). 
Table 4: IIT for Turkey's trade with selected EU countries in Manufactures

\begin{tabular}{|l|c|c|c|c|}
\hline \multicolumn{1}{|c|}{ (SITC 5-8) } & $\mathbf{1 9 7 5}$ & $\mathbf{1 9 8 0}$ & $\mathbf{1 9 8 5}$ & 1990 \\
\hline GERMANY & 0.12 & 0.16 & 0.23 & 0.27 \\
\hline UK & 0.08 & 0.16 & 0.37 & 0.27 \\
\hline FRANCE & 0.17 & 0.13 & 0.20 & 0.26 \\
\hline SPAIN & 0.12 & 0.15 & 0.16 & 0.26 \\
\hline GREECE & 0.58 & 0.32 & 0.32 & 0.39 \\
\hline PORTUGAL & 0.56 & 0.36 & 0.10 & 0.34 \\
\hline
\end{tabular}

Notes: 1.- The Grubel-Lloyd (unadjusted) index was calculated at the two digit level for each industry in manufactures (SITC 5-8) and unweighted averages were calculated across industries. 2.-Groups with unidirectional trade have not been included (i.e. where either exports or imports are zero).

A number of conclusions can be drawn from Table 4. First, it seems that the level of IIT for Turkey's trade with the industrialised EU countries (especially with the UK) and with Spain has significantly increased between 1975 and 1990 though the amount of IIT for these countries is still below the level of IIT for EU12 in most periods.

Secondly, the level of IIT for Turkey's trade with Greece and Portugal (whose factor endowments are considered to be similar with Turkey's) appears to be greater than that of the industrialised countries, however, it has a decreasing trend over time. As Nilsson (1997) points out, this may be a basic result of Greece and Portugal being small countries and thus having relatively low trade imbalances in their trade with Turkey ${ }^{16}$.

\subsubsection{A comparison of IIT level for Spain, Greece and Portugal with that of Turkey}

In order to have a closer look at the IIT levels for these three nonindustrialised southern European countries and to compare them with that of Turkey, we examine the IIT indices for each of these countries. Table 5 below shows the IIT indices for Spain, Greece and Portugal at 2 digit over the period between 1975 and 1990. 
Table 5 : IIT indices for Spain, Greece and Portugal at 2-digit level

\begin{tabular}{|l|c|c|c|c|}
\hline $\begin{array}{l}\text { Commodity Groups } \\
\text { (SITC) }\end{array}$ & 1975 & 1980 & 1985 & 1990 \\
\hline Spain & & & & \\
\hline Non-manufactured (0-4) & 0.29 & 0.41 & 0.41 & 0.44 \\
\hline Manufactured (5-8) & 0.54 & 0.63 & 0.61 & 0.71 \\
\hline Overall (0-8) & 0.43 & 0.53 & 0.53 & 0.59 \\
\hline Greece & & & & \\
\hline Non-manufactured (0-4) & 0.33 & 0.34 & 0.38 & 0.40 \\
\hline Manufactured (5-8) & 0.41 & 0.39 & 0.38 & 0.32 \\
\hline Overall (0-8) & 0.38 & 0.37 & 0.38 & 0.36 \\
\hline Portugal & & & & 0.37 \\
\hline Non-manufactured (0-4) & 0.35 & 0.39 & 0.37 & 0.49 \\
\hline Manufactured (5-8) & 0.50 & 0.48 & 0.54 & 0.44 \\
\hline Overall (0-8) & 0.43 & 0.44 & 0.47 & . \\
\hline
\end{tabular}

1.- The Grubel-Lloyd (unadjusted) index was calculated for each industry and unweighted averages were calculated across industries. 2.- Groups with unidirectional trade have not been included (i.e. where either exports or imports are zero).

An examination of Table 1 and Table 5 indicates, first, that the overall IIT level for these three southern European countries appears to be greater than that of Turkey. Secondly, regarding the IIT in nonmanufactured goods, the IIT level for the four countries under consideration seems to be fairly similar. However, with regard to manufactured goods, the evidence suggests that Spain, the most industrialised of the three countries, did have higher levels of IIT than the other three countries.

\subsubsection{An industry specific analysis of IIT for Turkey}

Following the country specific analysis of IIT for Turkey, in this section I present an industry specific analysis of IIT for Turkey. Table 6 shows the level of IIT for some selected manufacturing industries (SITC 5-8) over time and indicates that the level of IIT has notably increased for majority of industries. The level of IIT seems to be particularly high in essential oils (55), rubber (62), non-metallic minerals (66) and manufactures of metal (69). 
The high IIT level in resource-based and labour-intensive industries [such as leather (61), textiles (65) and footwear (85)] seems to be contradictory since the extent of IIT is normally positively correlated with the degree of product differentiation which is generally assumed to be greater in high-tech industries than in resource-based and labour-intensive industries. Nevertheless, the leather, textile and footwear industries are typical labour intensive industries where the extent of product differentiation can be high, given the possible deployment of brands, labels and advertising efforts.

Interestingly, the level of IIT for industries in which Turkey is considered to have a comparative advantage [e.g., leather (61), textiles (65) and clothing (85)] appears to be decreasing over the observation period (except for the slight increase in clothing in 1990).

Table 6: IIT for Turkey's total trade, selected manufacturing industries (SITC 5-8)

\begin{tabular}{|l|c|c|c|c|}
\hline SITC & 1975 & 1980 & 1985 & 1990 \\
\hline $51 \quad$ Organic chemicals & 0.02 & 0.08 & 0.13 & 0.36 \\
\hline $52 \quad$ Inorganic chemicals & 0.12 & 0.30 & 0.32 & 0.46 \\
\hline $\begin{array}{l}54 \quad \text { Medicinal and } \\
\text { pharmaceutical products }\end{array}$ & 0.10 & 0.09 & 0.34 & 0.45 \\
\hline $\begin{array}{l}55 \quad \text { Essential oils \& perfume } \\
\text { materials }\end{array}$ & 0.36 & 0.69 & 0.85 & 0.83 \\
\hline $\begin{array}{l}58 \quad \text { Artificial resins, plastic } \\
\text { materials }\end{array}$ & 0.0002 & 0.01 & 0.27 & 0.47 \\
\hline $\begin{array}{l}59 \quad \text { Chemical materials and } \\
\text { products }\end{array}$ & 0.05 & 0.02 & 0.33 & 0.15 \\
\hline $\begin{array}{l}61 \quad \text { Leather, leather } \\
\text { manufactures }\end{array}$ & 0.91 & 0.58 & 0.64 & 0.14 \\
\hline $62 \quad$ Rubber manufactures, & 0.14 & 0.75 & 0.70 & 0.63 \\
\hline $\begin{array}{l}65 \quad \text { Textile yarn, fabrics, } \\
\text { related products }\end{array}$ & 0.75 & 0.37 & 0.24 & 0.56 \\
\hline $\begin{array}{l}66 \quad \text { Non-metallic mineral } \\
\text { manufactures }\end{array}$ & 0.79 & 0.66 & 0.47 & 0.81 \\
\hline $68 \quad$ Non-ferrous metals & 0.12 & 0.41 & 0.62 & 0.61 \\
\hline $69 \quad$ Manufactures of metal & 0.29 & 0.30 & 0.71 & 0.72 \\
\hline
\end{tabular}




\begin{tabular}{|c|c|c|c|c|}
\hline $\begin{array}{l}71 \text { Power generating machinery } \\
\text { and equipment }\end{array}$ & 0.01 & 0.02 & 0.36 & 0.17 \\
\hline 73 Metalworking machinery & 0.01 & 0.02 & 0.12 & 0.19 \\
\hline $\begin{array}{l}75 \text { Office machines \& data } \\
\text { processing equipment }\end{array}$ & 0.0002 & n. $\mathrm{a}^{2}$ & 0.004 & 0.08 \\
\hline $\begin{array}{l}76 \quad \text { Telecommunications \& } \\
\text { sound recording apparatus }\end{array}$ & 0.006 & 0.19 & 0.19 & 0.74 \\
\hline $\begin{array}{l}77 \text { Electrical machinery, } \\
\text { apparatus \& appliances . }\end{array}$ & 0.02 & 0.19 & 0.36 & 0.30 \\
\hline 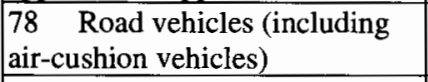 & 0.06 & 0.48 & 0.39 & 0.22 \\
\hline $79 \quad$ Other transport equipment & 0.02 & 0.0009 & 0.04 & 0.24 \\
\hline $\begin{array}{l}83 \text { Travel goods, handbags } \\
\text { and similar containers }\end{array}$ & 0.04 & 0.06 & $\mathbf{0 . 0 2}$ & 0.13 \\
\hline $\begin{array}{l}84 \text { Articles of apparel and } \\
\text { clothing accessories }\end{array}$ & 0.004 & 0.0002 & 0.002 & 0.009 \\
\hline 85 Footwear & 0.01 & 0.26 & 0.41 & $\mathbf{0 . 7 2}$ \\
\hline $\begin{array}{l}87 \text { Professional, scientific \& } \\
\text { controlling instruments }\end{array}$ & 0.01 & 0.005 & 0.26 & 0.06 \\
\hline
\end{tabular}

Notes: 1.- The Grubel-Lloyd (unadjusted) index was calculated at the two digit level for each industry in manufactures (SITC 5-8). 2.- Trade was unidirectional for this industry (i.e. where either exports or imports are zero). 3.- Figures in bold denote cases where there has been a distinct increase in IIT over time.

\section{Conclusion}

This paper examines the trend of IIT for Turkey and its determinants over period between 1975 and 1990 (pre- and postliberalisation periods) using cross-sectional time series data. The first goal of the study is to analyse if there has been any change in patterns of IIT after the implementation of Turkey's liberalisation program in the early 1980s.

Although there is no clear-cut theoretical or empirical basis for the relationship between IIT and trade liberalisation, our results on the trend of IT for Turkey suggest that there has been a notable increase in the overall level of IIT for Turkey particularly after the 1980s liberalisation program. This expansion in IIT was confirmed by comparing the level of IIT for non-manufactured and manufactured 
goods respectively and by examining IIT indices for Turkey's trade with the EU12.

Our results also indicate that not only the level but also the proportion of IIT (measured by marginal intra-industry trade, MIIT, indices) has increased over the same period. Therefore, this provides support for the proposition that trade liberalisation encourages IIT. Considering the increase in inter-industry trade over the liberalisation period, one can argue that the prediction of the recent new trade theory (NTT) -an increase in both inter- and intra-industry specialisation following liberalisation- appears to be appropriate for Turkey's liberalisation experience.

The examination of IIT in Turkey's trade with EU12 and its comparison with Turkey's total trade reveal some important insights on the relationship between IIT in multilateral trade and IIT withinregional trade. The overall level of IIT in Turkey's total trade seems to be notably greater than that of Turkey's regional trade with the EU12 over the period considered. This may be basically due to dissimilarity of demand conditions (i.e. taste overlap) between Turkey and the EU12. Comparison of the IIT level for Spain, Greece and Portugal with that of Turkey suggests that the overall IIT level of the three southern EU countries has been notably higher than that of Turkey over the observation period while IIT level in non-manufactured goods appears to be similar for all.

In this paper we show that the two-way trade (IIT) between Turkey and the EU has increased over the pre- and post liberalisation periods. One possible source of the increase in IIT between Turkey and the EU might the fact that GNP of Turkey has grown very fast in the 1980s (i.e. the average GNP growth of Turkey between 1980 and 1998 was about 5 percent). As the income gap between Turkey and EU falls we expect an increase in variety of products consumed in two regions which would enhance IIT level in trade between the two regions. However, the trend of GNP growth in Turkey in the 1960s and 70s 
makes such an explanation on IIT growth rather difficult as GNP growth in pre- liberalisation period has been as high as post liberalisation period in Turkey.

The policy implication of the impact of trade liberalisation on the extent of IIT is linked with the relationship between IIT level and structural adjustment costs. Intuitively, it is argued that adjustment costs are lower in industries with high levels of IIT. The possibility of lower adjustment costs suggests that the prospects for freeing trade flows are higher when more of existing and potential trade is of the intra-industry type. The policy implication of this for Turkey is that the liberalisation attempt in the 1980s was a step in the right direction and that further liberalisation of trade (i.e. joining a common market, the EU) may lead to further reductions in adjustment costs, reflected in a smaller net change in the number of firms, employment and turnover.

\section{Endnotes}

${ }^{1}$ This proposition has been tested by Finger (1975) and Hansson (1989) with inconclusive results.

${ }^{2}$ For surveys of the literature on IIT, see Tharakan (1983) Greenaway and Miller (1986, 1987), Lloyd (1989), Hansson (1989).

${ }^{3}$ However, as Brulhart (1998) argues, the upward trend in IIT cannot be taken as a straightforward confirmation of the new theories since the observed rise of IIT has occurred alongside a generalised fall in trade costs.

${ }^{4}$ Other studies on this area are; Balassa (1979), Havrylshyn and Civan (1983), Drabek and Greenaway (1984), and Globerman and Dean (1990).

${ }^{5}$ However, they find that the intra-industry pattern of new trade stimulated by trade liberalisation may differ from that established under protection.

${ }^{6}$ See Lundberg and Hansson (1986) for further discussion.

${ }^{7}$ Hamilton and Kniest (1991) examines the relationship between structural change and IIT for Australian manufacturing and find that there is some evidence trade liberalisation has induced more structural adjustment - and higher adjustment costs in industries characterised by inter-industry rather than intra-industry trade. 
8 Pagoulatos and Sorensen (1975), Toh (1982), Greenaway and Miller (1984), Hamilton and Kniest (1991), and Lunberg (1992).

${ }^{9}$ Toh (1982), Globerman and Dean (1990), Hamilton and Kniest (1991), Lundberg (1992), Ballance et al. (1992) are examples of recent studies that do not correct IIT indices for the overall trade imbalance. Bergstrand (1990) uses the adjusted GL index.

${ }^{10}$ See Greenaway and Miller (1986) for an authoritative discussion.

${ }^{11}$ Greenaway et al. (1994).

${ }^{12}$ See Brulhart (1994) for a comprehensive description of these indices.

${ }^{13}$ See Greenaway and Miller (1986) for a detailed explanation of the statistical properties of this index.

${ }^{14}$ Though the GL indices are principally used to measure IIT in manufacture, in order to observe the trend of IIT in non-manufactured goods and in total trade as well, the IIT indices are estimated for non-manufactured (0-4) and manufactured (58) goods separately, and for overall trade (0-8).

${ }^{15}$ In 1990 non-manufactured (manufactured) goods constituted about $30 \%(70 \%)$ of Turkey's total exports.

${ }^{16}$ See Nilsson (1997) for a comparison of German's IIT with small and large countries and for an industry specific analysis of German's IIT with Turkey.

\section{Bibliography}

Adler, M. (1970), Specialisation in the European Coal and Steel Community, Journal of Common Market Studies, 8, pp.175-91. Andreosso-O'Callahgan, B., and Noonan, C.A. (1996), European Intra-Industry Trade,

Emerging Industrial Specialisation in Central and Eastern Europe, Journal of World Trade, 30, pp.139-168.

Balassa, B. (1979). Intra-industry trade and the integration of the developing countries in the world economy, in Gierch (1979).

Balassa, B.(1986) The Determinants of Intra-Industry Specialisation in United States Trade, Oxford Economic Papers, 38, pp.220233.

Balassa, B. and Bauwens, L. (1987) Intra-industry specialisation in a multi-country and multi-industry framework, Economic journal, 97, pp.923-39. 
Balassa, B. and Bauwens, L.(1988) Inter-industry and intra-industry specialisation in manufacturing goods, Weltwirtschaftliches Archiv, 124, pp.1-13.

Ballence, R., Forstner, H., Sawyer, W.C. (1992), An empirical examination of the role of vertical product differentiation in North-South trade, Weltwirtschaftliches Archiv, 128, pp.330338.

Bergstrand, J.H. (1990) "The Heckscher-Ohlin-Samuelson model, the Linder hypothesis and the determinants of bilateral intraindustry trade, Economic journal, 100, pp.1216-1229.

Brulhart, M. and McAleese, D.(1995) Intra-Industry Trade and Industrial Adjustment: The Irish Experience, The economic and social Review, 26, pp.107-129.

Brulhart, M. (1994) Marginal intra-industry trade: measurement and relevance for the pattern of industrial adjustment, Weltwirtschaftliches Archiv, 130, pp.600-613.

Brulhart, M. (1998) Economic Geography, Industry Location and Trade: The evidence, World Economy, 21, No.6, pp.775-801.

Caves, R.E. (1981) Intra-industry trade and market structure in the industrial countries, Oxford Economic Papers, 33, 203-23.

Cox, D. And Harris, R. (1985), Trade liberalisation and industrial organisation: some estimates for Canada, Journal of Political Economy, 93, No.1, pp.115-145.

Drabek, Z. and Greenaway, D. (1984) Economic integration and intra-industry trade: the CMEA and EEC compared, Kyklos, 37, pp.444-69.

Finger, J.M. (1975) Trade overlap and intra-industry trade, Economic Inquiry, 13, pp.581-9.

Gierch, H. (1979), On the economics of Intra-Industry Trade, Tubingen, J.C.B.

Mohr.Goldstein, M. and Khan, M.S. (1976), Large versus small price changes and the demand for imports, IMF Staff Papers, 3, pp. 200-225. 
Globerman, S., Dean, J.W. (1990), Recent trends in Intra-Industry Trade and their Implications for Future Trade Liberalisation, Weltwirschaftliches Archiv, 126, pp. 25-49.

Globerman, S.(1992), North American trade liberalisation and intraindustry trade, Weltwirtschaftliches Archiv, 128, pp.487-497.

Greenaway, D., Miller, C.R. (1984) A cross section analysis of intra industry trade in the UK, European Economic Review, 25, pp.319-44.

Greenaway, D., Tharakan, P.K.M. [eds](1986), Imperfect Competition and International trade, Brighton: Wheatsleaf Press.

Greenaway, D. and Miller, C.R. (1986) The economics of IntraIndustry Trade, Oxford, Basil Blackwell.

Greenaway, D. and Miller, C.R.(1987) Intra-Industry Trade: Current Perspectives and Unresolved Issues, Weltwirschaftliches Archiv, 123, pp.39-57.

Greenaway, D., Hine, R.C., Milner, C., Elliott, R. (1994)Adjustment and the measurement of marginal intra-industry trade, Weltwirtschaftliches Archiv, 130, pp. 418-427.

Grubel, H.G., Lloyd, P.J. (1975), Intra Industry Trade, London, Macmillan. Hal

Mason, R. and Sakong, I. (1971), Level of Economic Development and Capital-Labour

Ratios in Manufacturing, The review of Economics and Statistics, 53, pp. 176.

Hamilton, C. and Kniest, P. (1991) Trade liberalisation, structural adjustment and intra-industry trade - a note, Weltwirtschaftliches Archiv, 127, pp.356-367.

Hansson, P.(1989) Intra-Industry Trade: Measurements, Determinants and Growth. A study of Swedish Foreign Trade, University of Umea, Umea Economic Studies No.205.

Havrylshyn, O. and Civan, E. (1983) Intra-Industry trade and the stage development: a regression analysis of industrial and developing countries, in Tharakan (1983). 
Kol, J., Mennes, L.B.M. (1989) Corrections for trade imbalance - a survey Weltwirtschaftliches Archiv, 125, pp.703-717.

Kol, J., Tharakan, M.(1989) Intra-Industry Trade. Theory, Evidence and Extensions, London.

Krugman, P. (1980) Scale economies, product differentiation and the pattern of trade, American Economic Review, 70, pp.950-9.

Krugman, P. (1981) Intra-industry specialisation and the gains from trade, Journal of Political Economy, 89, pp.959-73.

Krugman, P.R.(1983), New Theories of Trade among Industrial countries, American Economic Review, Papers and Proceedings, 73, pp.343-47.

Krugman, P.R. (1998). What's is new about the new geography?, Oxford Review of Economic Policy, 14, pp.7-17.

Krugman, P.R. (2000), Technology, trade and factor prices, Journal of International Economics, 50, pp.51-71.

Lipsey, R.G (1976) Review of Grubel and Lloyd (1975), Journal of International Economics, 6, pp.312-14.

Lloyd, P.J. (1989) Reflections on Intra-Industry Trade Theory and factor proportions, In Kol and Tharakan (1989), pp.15-30.

Loertscher, R., Wolter, F.(1980) Determinants of intra-industry trade: among countries and across industries, Weltwirschaftliches Archiv, 116, pp.281-93.

Lundberg, L. (1992) Economic integration, inter- and intra-industry trade - the case of Sweden and the EC, Scandinavian journal of economics, 94, pp.393-408.

Lundberg, L., Hansson, P. (1986) Intra-industry trade and its consequences for adjustment, In Greenaway and Tharakan (1986).

Marvel, H.P., Ray, E.J. (1987) "Intra-industry trade - sources and effects on protection" Journal of political economy, 95, pp.1278-1291.

Menon, J., Dixon, P.B. (1997), Intra-Industry versus Inter-Industry Trade: Relevance for Adjustment Costs, Weltwirschaftliches Archiv, 133, pp.164-169. 
Nilsson, L. (1997) The Measurement of Intra-Industry Trade between Unequal Partners, Weltwirschaftliches Archiv, 133, pp. 554565.

Norman, V. (1989), EFTA and the Internal European Market, Economic Policy, 9, pp.424-65.

Pagoulatos, E., Sorensen, R. (1975), Two-way international trade: an econometric analysis, Weltwirschaftliches Archiv, 111, pp.45465.

Smith, A., Venables, A. (1988) Completing the Internal Market in the European Community: Some Industry Simulations, European Economic Review, 32, pp.1501-25.

Tharakan, P.K.M. (ed.)(1983), Intra-industry Trade: Empirical and Methodological Aspects, Amsterdam, North Holland.

Toh, K. (1982), A cross-sectional analysis of intra-industry trade in US manufacturing industries, Weltwirschaftliches Archiv, 118, pp.281-300.

Vona, S. (1991) On the Measurement of Intra-Industry Trade: Some Further Thoughts, Weltwirschaftliches Archiv, 127, pp.678-700. 